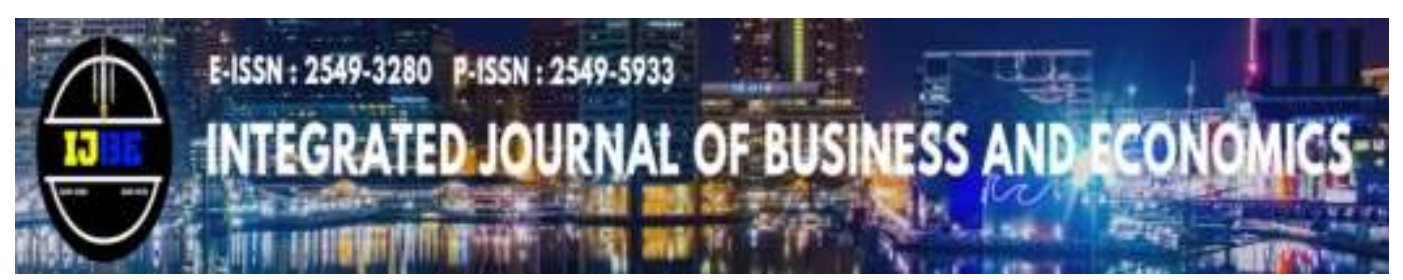

Email: ijbe.feubb@gmail.com

Laman: http://ojs.ijbe-research.com/index.php/IJBE/index

\title{
Indonesia's Civil Servants' Performance at Aviation Engineering: Exploration Study
}

\author{
Wirma Yuliana $^{a}$, Anita Maharani ${ }^{b}$, Zainur Hidayah \\ ${ }^{a, c}$ Open University, Indonesia \\ ${ }^{b}$ Bina Nusantara University, Indonesia \\ anita.maharani@binus.edu
}

\begin{abstract}
The purpose of this study is to see what contributes to organizational performance in Aviation Engineering, one of the government institutions in Indonesia. Individuals commit organizational performance in the organization. In practice, performance is related to workload, the higher the workload. Studies show that optimal individual performance can drive organizational performance to increase. The method used in this study is qualitative, with the word cloud analysis of interviews with informants who are considered by the parameters of the research and, in addition to primary data, also uses secondary data. The results obtained from this study indicate that to encourage performance, there needs to be an implementation of rewards for those who work well and penalties for those who do not function optimally. This research suggested that this organizations should improve their policy in regard to individual workloads that promotes organizational performance, such as improving allowances and adjusted workload.
\end{abstract}

\section{Article Info}

- Received : April 30, 2020

- Revised : June 9, 2020

- Published : June 16, 2020

- No. Pages : 160 - 169

- DOI : 10.33019/ijbe.v4i2.279

- JEL : L25, P47

- Keywords : performance, civil servants, implementation, exploration study 


\section{Introduction}

The performance of individual employees greatly influences organizational success. Performance is the responsibility of every individual who works in an institution or an organization. Excellent performance is the optimal result of work and by corporate standards and supports the achievement of organizational goals. Improved employee performance will bring progress for agencies (organizations) to survive in an unstable competition. The success of optimal employee performance can be seen from employee welfare and factors that support employee performance. Sutrisno (2010) concluded that employee performance is the result of employee work seen in aspects of quality, quantity, working time, and cooperation to achieve goals that have been set jointly by the organization. This also applies to government-owned organizations, as the focus of this study is to raise government-owned public organizations.

In Indonesia, the government is developing various types of public sectors, including the development of air transportation (Kadarisman, Gunawan, Ismiyati, 2015). The development of air transportation is being developed by the government, considering that Indonesia's population continues to increase, and community mobilization is also getting higher. Kadarisman, et al (2015) mentioned infrastructure development in Indonesia, both in terms of airports and aircraft continues to be improved from all aspects such as service, maintenance, aircraft fleet expansion, airport expansion and the addition of new airports, not only that the government itself is improving air transportation facilities so that it is much more modern and high-tech. Therefore, to achieve this, all needed support from various parties, both from the side of the community as beneficiaries of transportation services and the government as regulators and providers of air transportation services.

The government's role in overseeing air transportation is carried out by the Ministry of Transportation through the Directorate General of Civil Aviation. The Directorate General of Civil Aviation as the supervisor and provider of air transportation services has a significant role in overseeing airport activities throughout Indonesia to maximize air transportation services and safety (Tabaru, Rumapea, and Tampongangoy, 2016). The Directorate General of Civil Aviation's primary purpose can be seen from the readiness of the airport in preparing flight facilities and infrastructure. Includes flight schedules, aircraft hangars, aircraft crossings, waiting rooms, and maintenance of all facilities and support itself.

Achievement obtained by the Ministry of Transportation, in this case, the Directorate General of Civil Aviation, is inseparable from the role of human resources who carry it out. The performance of potential human resources in the Ministry of Transportation that fosters the development of transportation today. The potential of every human resource in an organization must be utilized as well as possible to provide optimal work. The achievement of the goals set by an organization depends not only on modern equipment, facilities, and complete infrastructure but also on the people who carry out the work. 
Based on research through interviews conducted by researchers in 2019 to several employees, it is known that Aviation Engineering Employees often feel disadvantaged by the performance appraisal process. The performance appraisal they feel prefers the quantity of time and overrides the results of the work done. One of the complaints employees are late attendance, where there are rules if being new, will cause a cut in the performance allowance that they get, but the number of overtime hours does not count.

Another thing that has an impact on employee performance is the workload. Based on Permendagri No. 12/2008, the workload is the amount of work that must be assumed by an office / organizational unit and is the product of work volume and time norms. At the Aeronautical Engineering Center, the workload owned by employees is enormous, where the work carried out concerns the smooth flight of all airports in Indonesia.

The realization of Air Transportation performance targets in several aspects is optimal. Namely, employees in the unit to be investigated experience the inability to deal with all work conditions in the field. There are problems employees face in connection with the implementation of company policies, making them feel uncomfortable working. Heavy workloads are not supported by reasonable procedures such as cutting performance benefits not based on work results but absenteeism. While, Kang, Yu and Lee (2016) mentioned type of industry may contribute on benefits effect on employee performance, and in the long term will determine how engaged the employees to organizations. Then Itta, Rantetampang and Tobing (2017) mentioned that benefits should be maintained and improved in order to stimulate civil servants more eager to perform. If civil servants as subject of this study feel being untreated well, but the regulations has already stated policies to measure civil servants employees workload, therefore based on the background and formulation of the problem above, the research question is as follows "How civil servants at the Aeronautical Engineering Hall perceived their performance?"

\section{Literature Review}

Performance comes from understanding performance. There are many explanations about the term performance, but researchers find that there are those who give a sense of accomplishment as work results or work performance. On the other hand, performance has a broader meaning, not only the results of work and how the work process takes place. Performance is the result of work that has a strong relationship with the organization's strategic objectives, customer satisfaction, and contribution to the economy (Wibowo, 2014). Thus, performance is about doing work and the results achieved from work.

Pasolong (2011), mentioned factors influence employee performance are as follows:

1. Ability, namely the knowledge in a field that is influenced by talent, intelligence (intelligence), and interest. 
2. Willingness, namely the desire to issue a level of effort high for organizational purposes.

3. Energy, which is a source of strength from within a person.

With the energy, a person can respond and react to whatever is needed, without thinking long or conscious attention so that the mental acuity and concentration in managing work becomes higher, d) technology, namely the application of existing knowledge to facilitate in doing work, e) compensation, which is something that is received by the employee as a reward for performance and benefit to him, f) clarity of objectives, that is, the goals to be achieved by the employee. This goal must be clear so that the work carried out by employees can be directed and run more effectively and efficiently, g) security, which is a fundamental human need, because generally, someone who feels safe doing his work will affect his performance.

According to Hart and Staveland (Tarwaka, 2014), that workload is emerging from the interaction between the demands of work environment tasks, which are used as workplaces, skills, and perceptions of workers. Workloads are sometimes operationally defined on factors such as job demands or efforts made to do work. The workload is an issue that arises from interactions between the needs of work environment tasks, which are used as workplaces, skills, and perceptions of workers.

According to Widodo (2015), the principle of compensation must be based on the principle of fairness and faith of worth and pay attention to the applicable Labor Law, as follows: a) the principle of justice and b) the policy of feasible and reasonable. The performance allowance system at the Ministry of Transportation refers to the Ministerial Regulation No. 41 of 2017 which states "Performance Allowances are benefits provided to Employees which are a function of the successful implementation of bureaucratic reforms and are based on those employee performance achievements that are in line with the performance achievements of the organization where the Employee work." The performance allowance system at the Ministry of Transportation is provided with the following conditions:

1. The payment of the Performance Allowance is submitted for each month.

2. The amount of the Performance Allowance is made by the mechanism through the account of the employee concerned.

3. The calculation of the Performance Allowance is carried out with a new system based on the calculation of employee performance achievements.

According to Maneaba in Tarwaka (2011), the workload is influenced by two factors, namely: a) external factors, namely the burden originating from outside the worker's body, such as; physical tasks, such as work stations, spatial planning, workplaces, work tools and facilities, working conditions, work attitudes, and psychological duties, such as work complexity, difficulty level, work responsibilities, and then work organization, such as the length of time worked, rest periods, work shifts, night work, wage systems, organizational structure 
models, a delegation of duties and authority. Finally, the work environment is the physical work environment, chemical environment, biological work environment, and psychological work environment. Then $b$ ) internal factors, factors originating from the body itself as a result of external workload reactions. Internal factors include physical factors (sex, age, body size, nutritional status, and health conditions) and psychological factors (motivation, perception, beliefs, desires, and satisfaction).

In a previous study, performance allowance improves employee performance (Puluhulawa, 2013), implementation of performance benefits has been running, but there are still irregularities in its management (Prabowo, Hafel, Purwanto, Anfas, 2019), provision of performance benefits was less valid (Mahendra, 2016)

\section{Research Methods}

In this study, researchers took interviewees in each section that was considered to be representative of all employees of the Technical Implementation Unit (UPT) Institute of Aeronautical Engineering. Sampling or data sources (interviewees) in this study were conducted purposively and for the sample size determined by a snowball, as listed in Table. 1.

The following is a list of resource criteria.

Table 1. Interviewee Criteria

\begin{tabular}{|c|c|c|c|}
\hline & Position & Criteria & $\begin{array}{c}\text { Number of } \\
\text { Interviewees }\end{array}$ \\
\hline Interviewee 1 & $\begin{array}{l}\text { Head of } \\
\text { Aviation } \\
\text { Engineering } \\
\text { Center }\end{array}$ & Decision maker & 1 person \\
\hline Interviewee 2 dan 3 & Staff & $\begin{array}{l}\text { Achiever based of } \\
\text { individual KPI } \\
\text { results }\end{array}$ & 2 person \\
\hline Interviewee 3 dan 4 & Staff & $\begin{array}{c}\text { Non-achiever } \\
\text { based on } \\
\text { individual KPI } \\
\text { results }\end{array}$ & 2 person \\
\hline Interviewee 5 sampai 7 & Techinician & $\begin{array}{l}\text { Heavy workload } \\
\text { and achiever }\end{array}$ & 3 person \\
\hline Interviewee 8 sampai 11 & $\begin{array}{c}\text { General } \\
\text { administration }\end{array}$ & $\begin{array}{l}\text { Heavy workload } \\
\text { and non-achiever }\end{array}$ & 3 person \\
\hline
\end{tabular}

Source: Data processed, 2020

The analysis of this research instrument uses the narrative analysis method from the results of in-depth interviews. We use a text analysis visualizer using a word cloud generator, accessed online through www.wordclouds.com, from interview results. According to Rahmat (2012), an in-depth interview is a process of obtaining information for research purposes using question and answer while face to face between the interviewer with the interviewee or interviewee, with or without using interview guidelines, where the interviewer is involved in the social life of the interviewee. 


\section{Results}

From all of the interviewees, there are ten out of eleven who stated that benefits for performance would affect their performance. According to the interviewee, by providing benefits, the organization will help the interviewee strive for better performance, and by the meantime, it will also increase employee work discipline. This result is consistent with Robbins and Coulter (2012), who stated that the provision of compensation aims to increase employee motivation and improve employee discipline at work.

They are related to interview results about the provision of performance allowances to Aviation Engineering Center employees. Results show that most interviewees feel that their performance allowance has met fairness, but interestingly, some interviewees consider it has not met fairness. This is related to the workload of employees who are not yet proportional. While employees who have more workloads feel less time to complete their work, this has an impact on the value of the work discipline concerned, especially from the aspect of the working hour. It also has an impact on fulfilling the target of additional tasks because to do the workload that lacks time, and the employee also has to carry out other tasks. These conditions lead to the emergence of employee views that the performance allowance for them does not yet meet their expectancy. From the word cloud results (Picture.1), we may see clustered terms resulted from the interview. The bigger and bolder the name appears means it was the word most of the interviewee mentioned.

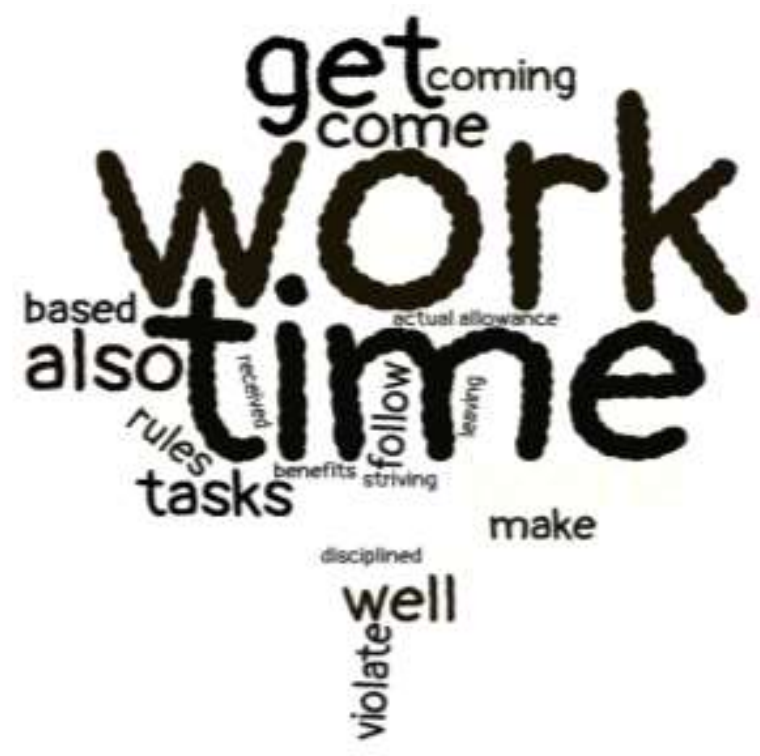

Source: Data processed, 2020

Figure 1. Wordcloud

But word cloud from interviewees is still not Organization, and therefore it needs more complementary data to justify whether interviewees' opinions are objectives. We then explore secondary data to complement interview results, as mentioned in Table. 2, as follow. 
Table 2. Civil Servants Performance

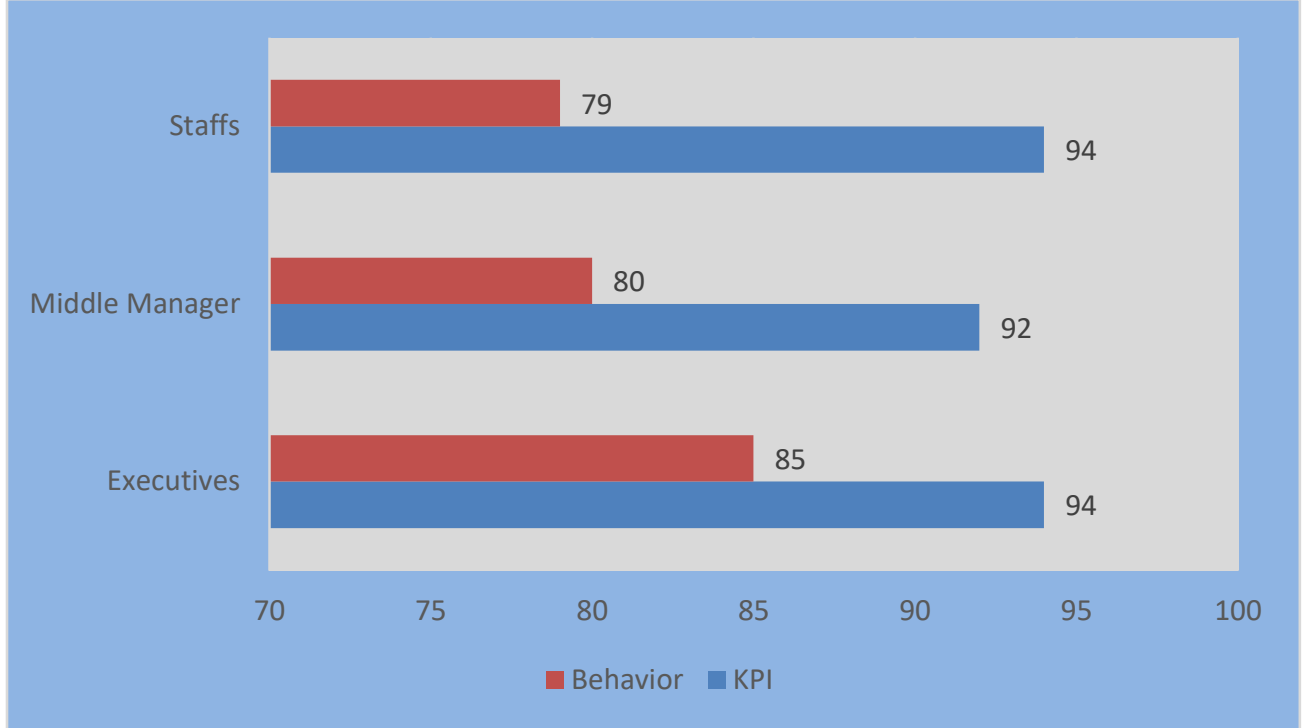

Source: Ministry of Transportation, 2018

The government performance appraisal system was appointed from Government Regulation No.46 of 2011, where the civil servant performance appraisal consists of the Employee Performance Objectives (KPI) and work behavior. While the assessment itself consists of:

a) Performance appraisal is done by combining KPI assessment with work behavior assessment.

b) The value of the elements of the KPI is $60 \%$, and the element of work behavior is $40 \%$

c) Employee performance appraisal is carried out by an appraisal official once in one) year.

d) Performance appraisal is carried out at the end of December in the year concerned and no later than the end of January the following year.

e) Performance scores of civil servants are stated in numbers and designations as follows:
1) 91 - up: perfect
2) 76 - 90: good
3) 61 - 75: enough
4) 51 - 60: less

From the table, we may see that KPIs from three positions are high scores, but their behavior is not average between locations. Results of the staff's behavior are lower than the middle manager and even executives. We need sufficient information to enhance our understanding of this issue. Therefore, we did some interviewee to confirm about secondary data, and the results show as follow.

First, we confirm the data to the first interviewee>

"For staff, it will depend on the assessment from their supervisors. If staff unable to show proper behavior that supports the work, their supervisors unable to rate high" - Interviewee 1 
From this statement, it can be understood that staff most probably didn't able to show good behavior from supervisors' mindset. But on the other side, when this was confirmed to interviewee 3 , the result shows as follows.

"It is automatically that supervisors or even leaders have good behavior and because they become an example for their subordinates" - Interviewee 3

Interviewee 3 was one of an achiever, and voluntarily involved in this result. From the result, we may then understand that the interviewee has a perspective on their supervisors, as mentioned above since they are mandated to show a good example; therefore, it was automatic for supervisors to get higher ratings compared with their subordinates.

Based on the results of the study, it can be seen that the performance of the Aeronautical Engineering Center from year to year has increased. Improved performance is indeed inseparable from the production of employees who also experienced an increase. Employee performance will affect the performance of work units where employees work and affect the performance of agencies. This performance measurement is by Moeheriono (2012) opinion, which states that general performance appraisal factors consist of four main elements, namely work results, behavior, attributes, and competencies, as well as comparability.

From the beginning of the discussion on the issue of performance benefits, aspects of employee discipline always emerge and become a separate problem for employees because employee performance is more important than employee discipline, even if it may be more extreme than employee discipline is not essential. Also though employee discipline is necessary, so the government in formulating regulations related to performance issues and performance benefits makes employee work discipline an element of assessment.

According to interviewees, the motivation they received was very helpful in improving employee performance, especially motivation in financial form. One of the most compelling motivations, according to Aviation Engineering Center employees, is one of them in the way of employee welfare benefits implemented in the form of wages or salary and performance allowances. In Saraswati opinion, motivation as a willingness to exert a high level of effort towards organizational goals is conditioned by the ability of efforts to meet some individual needs.

In addition to getting motivation in the form of Aviation Engineering Employees in the form of performance allowances, employees also receive motivation in the form of Guidance, Guidance, Direction, and Rewards or rewards. Reward received in the form of promotion, career development, and employee welfare. This is by the opinion of Mangkunegara (2012), which states that there are several principles in motivating employees: the principle of participation, the law of communication, the principle of recognizing the contribution of subordinates, and the principle of delegating authority and the principle of paying attention. 


\section{Conclusion and Suggestion}

In this study, there are some limitations including the availability of time provided by a limited research project, interviewees are less responsive in answering questions raised by researchers and providing answers that tend to lead to the interests of individual interviewees.

To improve the performance of the Aeronautical Engineering Office employees, the motivational method is providing performance benefits to employees and providing rewards and punishment. Granting performance allowances for Aviation Engineering Institute employees affects improving employee performance both in terms of work discipline and employee performance.

Based on the results of this study, some suggestions put forward to be considered or prioritized in the context of providing performance allowances in improving agency performance, making workloads adjusted to the ability of employees and the availability of sufficient time, so that there is no Qualitative overload and Quantitative overload.

Increased motivation for employees by considering the effectiveness of motivation, such as promotion, career development, and employee welfare, especially in the form of performance benefits. Institutions also able to improve employee work discipline by enforcing discipline and finding alternative solutions as evidence of employees coming to work besides using fingerprint.

\section{Acknowledgement}

This research is part of a thesis written by Wirma Yuliana at the Open University, which was successfully defended in March 2020. The author would like to thank all those who have helped.

\section{References}

1) Itta, Debora; Rantetampang, AL; Tobing, H. L. (2017). Factors Affecting The Performance of Civil Servants District Health Department Boven Digoel. International Journal of Sciences: Basic and Applied Research (IJSBAR), 31(1), 213-224.

2) Kadarisma, Muhammad; Gunawan, A. I. (2015). Implementasi Kebijakan Sistem Transportasi Darat dan Dampaknya terhadap Kesejahteraan Sosial di Jakarta. Jurnal Manajemen Transportasi Dan Logistik (JMTransLog), 02(01), 59-78.

3) Kang, Dong Ung; Yu, Gun Jea; Lee, S.-J. (2016). Disentangling The Effects Of The Employee Benefits On Employee Productivity. The Journal of Applied Business Research, 32(5).

4) Mahendra. (2016). Efektivitas Pemberian Tunjangan Kinerja Daerah (Studi Pada Biro Perlengkapan Dan Aset Daerah Provinsi Lampung ). Universitas Lampung. 
5) Mangkunegara, Prabu, A. (2012). Manajemen Sumber Daya Manusia Perusahaan. PT. Remaja Rosdakarya Bandung.

6) Pasolong, H. (2011). Teori Administrasi Publik. Alfabeta.

7) Prabowo, Eko, Ady; Hafel, Muhlis; Purwanto, Joko, Agus; Anfas, A. (2019). The Implementation of Providing Performance Allowance Policy in the Secretariat of the General Election Commission Kota Ternate, Indonesia. Jurnal Ilmiah Ilmu Administrasi Publik, 9(2). https://doi.org/https://doi.org/10.26858/jiap.v9i2.11529

8) Puluhulawa, J. (2013). Regional Performance Allowance; Its Effect to Employee Performance and the Success of Local Government in Gorontalo Province, Indonesia. Public Policy and Administration Research, 3(12).

9) Rahmat, P. S. (2012). Penelitian Kualitatif. Equilibrium, 5(9), 1-8.

10) Robbins, Stephen P.; Coulter, M. (2012). Management (11th ed.). Pearson Education Limited.

11) Tabaru, Makswel Y; Rumapea, Patar; Tampongangoy, D. (2016). Fungsi Pengawasan terhadap Keselamatan Penerbangan Bandara Udara (Studi di Bandara Udara Kuabang Kao. Kab. Halmahera Utara). Jurnal Administrasi Publik UNSRAT, 3(38).

12) Tarwaka. (2014). Ergonomi Indutri: Dasar-Dasar Ergonomi dan Implementasi di Tempat Kerja (2nd ed.). Harapan Press.

13) Wibowo. (2014). Manajemen Kinerja (5th ed.). Rajawali Pers.

14) Widodo, S. (2015). Manajemen Pengembangan Sumber Daya Manusia. Pustaka Pelajar.

\section{Regulations}

1) Government Regulation. No. 46/2011. Evaluation of Employee Work Performance.

2) Minister of Home Affairs. No 12/2008. Guidelines for Analysis of Workload in the Department of Home Affairs and Local Government.

3) Ministry of Transportation. No. PM 41/2017. Procedures for Calculating and Providing Employee Performance Benefits in the Ministry of Transportation. 